ON THE WINGS OF TIME 



\section{ON THE WINGS OF TIME}

ROME, THE INCAS, SPAIN, AND PERU

Sabine MacCormack 
Copyright (c) 2007 by Princeton University Press

Published by Princeton University Press, 41 William Street, Princeton,

New Jersey 08540

In the United Kingdom: Princeton University Press, 6 Oxford Street,

Woodstock, Oxfordshire OX20 1TW

All Rights Reserved

Second printing, and first paperback printing, 2009

Paperback ISBN: 978-0-691-14095-7

The Library of Congress has cataloged the cloth edition of this book as follows

MacCormack, Sabine.

On the wings of time : Rome, the Incas, Spain, and Peru / Sabine MacCormack. p. cm.

Includes bibliographical references and index.

ISBN-13: 978-0-691-12674-6 (alk. paper)

ISBN-10: 0-691-12674-7 (alk. paper)

1. Incas-Historiography. 2. Incas-First contact with Europeans. 3. Incas in literature-History and criticism. 4. Indian literature-Andes Region-History and criticism. 5. Spanish literature-Andes Region-History and criticism.

6. Peru-History-Conquest, 1522-1548. I. Title.

F3429.M164 2007

985'.010722—dc22 2005037893

British Library Cataloging-in-Publication Data is available

This book has been composed in Palatino

Printed on acid-free paper. $\infty$

press.princeton.edu

Printed in the United States of America

$\begin{array}{lllllllll}10 & 9 & 8 & 7 & 6 & 5 & 4 & 3 & 2\end{array}$ 
For Harriet Zuckerman

to remember Arnaldo Momigliano

and with gratitude to the Andrew W. Mellon Foundation.

LARGIOR HIC CAMPOS AETHER ET LUMINE VESTIT

PURPUREO, SOLEMQUESUUM, SUA SIDERA NORUNT.

-Vergil, Aeneid VI, 640-641 
